\title{
Changing Trend of Occupation among the Brass Artisan Moria Community of Brahmaputra Valley, with special Reference to Kamrup District
}

\author{
Bishmita Medhi ${ }^{1}$, Prof. B.S. Mipun ${ }^{2}$, Sailajananda Saikia ${ }^{3}$ \\ ${ }^{1}$ Research Scholar, Department of Geography, NEHU, Meghalaya, India \\ ${ }^{2}$ Professor, Department of Geography, NEHU, Meghalaya, India \\ ${ }^{3}$ Assistant Professor, Department of Geography, M.C. College, Barpeta, Assam, India
}

\begin{abstract}
Occupational shift has become a common trend among the handicraft artisans in the changing economic situation of $20^{\text {th }}$ century world. The traditional brass artisan community of Assam; the Morias also show no difference in this regard. Once, the trusted canon and gun makers during Ahom regime and at present the traditional brass item manufacturer of Assamese society, the Morias are now a very backward community from economic, social and academic point of view. Present situation compels them to switch over to other tertiary activities abandoning their traditional brass metal work. But despite of these a group of enthusiastic Morias are trying to revive their traditional brass work.

An attempt has been made in this paper to discuss the present trend of occupational shifting of the Moria community and the causes behind this occupational diversification. Attempt has also been made to discuss their traditional occupation and the poor economic condition of the traditional brass artisans.
\end{abstract}

Keywords: Moria Community, Brass Crafting, Economic backwardness, Traditional occupation, Occupational shift.

\section{Introduction}

Assam is known as the land of Red River and Blue Hills. The region has been blessed with the vast fertile river valleys. Since time immemorial rivers have been the centre of human attraction where the great civilizations of the world evolved. The mighty Brahmaputra is no exception. Hot and humid climate together with the fertile alluvial soil make the entire Brahmaputra valley as an agriculturally rich region in South East Asia. Therefore, it is quite natural that agriculture is the mainstay of almost all ethnic groups of the region. The indigenous tribes of Assam, viz. the Bodos, the Mishings, the Rabhas, the Deuris, the Tiwas, the Karbis, the Dimasas, etc. along with the non-tribal ethnic groups like Koch, Kalita, Keot, Yogi (Nath), Muslims, etc. thrive mostly on cultivation. However, there are some other ethnic groups who prefer different occupation other than agriculture.

It has been observed that in Indian society, work based caste system is prevalent. In Assam too, similar caste based ethnic groups are very common. Here, the economic activity of a particular caste has never been challenged by other ethnic groups. For example, the ancestral occupation of the 'Kaibartas' is fishing. 'Hira' and 'Kumar' communities practiced pottery as their means of livelihood. While the 'Kumars' use potter's wheels to make earthen items used in temples and other religious places (Devagriha), the 'Hira' community make all the household utensils (potteries) without using any wheel. The 'Kamar' or Karmakar use iron to make agricultural and domestic tools and the Sonari or Swarnakars make gold and silver ornaments as their hereditary occupation. During the Ahom regime the Ahom Swargadews generated many work based castes like the Sonowals, Khargharia and many more. The ancient kingdom of Kamrupa was noted for many old time cottage industries. Many of these old age cottage industries received royal patronage and enriched the Assamese culture, becoming an integral part of the society.

Weaving is one of the most important traditional household occupations of the Brahmaputra valley. It is interesting to note that irrespective of caste, creed, community, religion or economic or social status, weaving is considered as an inseparable activity of every Assamese household carried out by the women folk of the region flourishing the vibrant and colourful Assamese culture.

Brass and bell metal works were highly developed throughout Assam in the past. Brass metal work is the ancestral occupation of the Moria Community people. According to Assam history tells, these people were originally warriors; it was during the battle of Hatbor and DuiMuniSila of Silghat in 1532 AD, the Muslim invaders were repulsed by the Ahoms and their General Turbaq was killed. In that battle the Ahoms captured 900 Muslim soldiers. Later, these prisoners were settled in different parts of Assam, married local Assamese Hindu girls and became an integral part of the society. Tradition says that they were at first ordered to cut grass for the king's elephants, but found quite unfit for this work. They were next employed as cultivators, but their 
ignorance of agriculture was so great that they stole mud from other people's paddy field and carried the stolen mud to their paddy field instead of ploughing land and planting the seedlings in it. The field (Khat) where the Moria people carried mud (Boka) for cultivation is now known as Bokakhat and the area from where the mud were collected is known as Moria Hola. Later, King came to know about their skill in machine works and employed them as cannon and gun maker in which they showed fine craftsmanship. They started manufacturing household and decorative brass items. Thus brass metal work gradually flourished with royal patronage and became a traditional occupation of Assamese society. With the development of science and technology, rapid urbanization of $20^{\text {th }}$ century world, a drastic change in the world economy came into existence. As a consequence of globalization, many ethnic groups are compelled to leave their ancestral occupation to cope with the changed economic structure. People switched over to other economic activities which can provide them a better socio economic life. Moria Community has also been facing the phase of occupational shifting while struggling to cope with the changed economic situation.

\subsection{STATEMENT OF THE PROBLEM:}

Moria community in general and the brass artisans in particular, are very backward from educational, social and economic perspective. They are recognized as MOBC by the government of India.

\subsection{STUDY AREA:}

The study has been undertaken in the Kamrup district of Brahmaputra valley. . Out of the total 6 Moria villages of Kamrup district 50\% i.e. three villages - Muslimpatty, Alta Malara and Islampatty have been selected for

study.

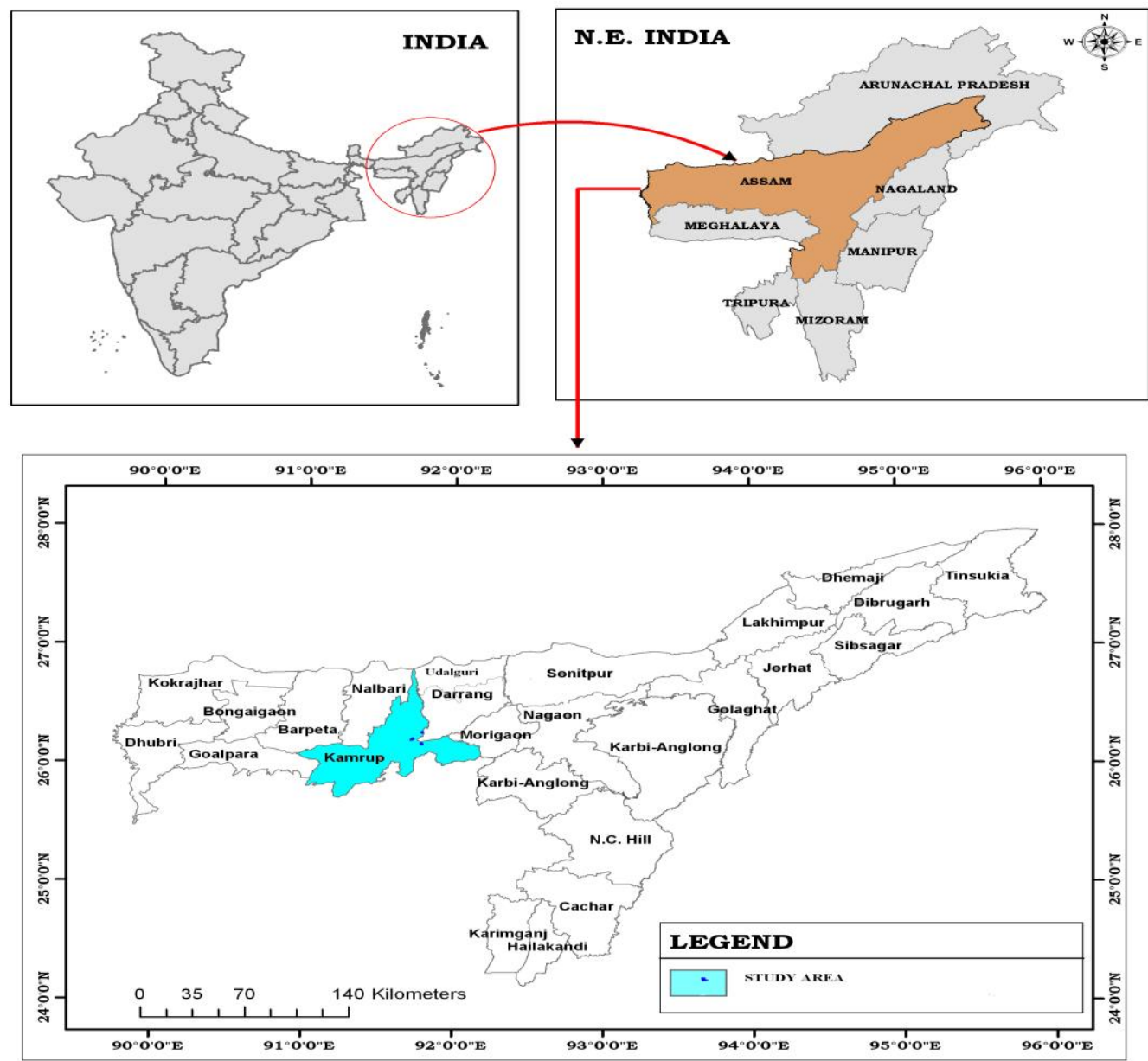

Source: Assam Remote Sensing and Space Application Centre

\subsection{DATA BASE AND METHODOLOGY:}

A total sample size of 270 Moria households has been selected from Kamrup district. Both primary and secondary data have been used for the study in order to get the present livelihood pattern, socio-economic 
conditions and changes in the occupation pattern of Moria community. General information of the study area and the Moria community has been collected from various secondary sources like Moria Association's census, Government records and article in books, journals and newspapers and from other reliable sources. Primary data have been collected from the selected Moria villages of Kamrup district through household questionnaires. For the field survey scheduled questionnaires were used to collect required data regarding the present occupational pattern and their trend of occupational shifting.

\subsection{PRESENT OCCUPATIONAL STRUCTURE OF THE MORIA OF KAMRUP DISTRICT:}

The following table shows the present trend of occupational structure of the Morias of Kamrup district.

Table 2.1: Occupational Structure of Morias of Kamrup District

\begin{tabular}{|c|c|c|c|c|c|c|}
\hline Occupation & Male & $\%$ & Female & $\%$ & Total & Percentage \\
\hline Cultivator & - & - & - & - & - & - \\
\hline Wage Labourer & 28 & 5.81 & 14 & 3.02 & 42 & 4.44 \\
\hline Brass Worker & 176 & 36.51 & - & & 176 & 18.60 \\
\hline Electrician & 15 & 3.11 & - & & 15 & 1.58 \\
\hline Machine Repair & 7 & 1.45 & - & & 7 & 0.74 \\
\hline Garage Worker & 9 & 1.87 & - & & 9 & 0.95 \\
\hline Livestock Trader & 5 & 1.04 & - & & 5 & 0.53 \\
\hline Tailoring & 14 & 2.90 & 8 & 1.72 & 22 & 2.32 \\
\hline Book Binder & - & - & - & - & - & - \\
\hline Business & 84 & 17.43 & - & - & 84 & 8.9 \\
\hline Govt. Service & 42 & 8.71 & - & - & 42 & 4.43 \\
\hline Private & 15 & 3.11 & 16 & 3.45 & 31 & 3.28 \\
\hline Housewife & - & - & 322 & 69.4 & 322 & 34.04 \\
\hline Student & 39 & 8.1 & 30 & 6.46 & 69 & 7.29 \\
\hline Unemployed & 48 & 9.96 & 74 & 15.95 & 122 & 12.9 \\
\hline Total & 482 & 100 & 464 & & 946 & 100 \\
\hline
\end{tabular}

Source: Field survey, 2009

Out of the total working males $36.51 \%$ are in traditional brass work, followed by the business category with $17.43 \%$. Only $8.71 \%$ Morias of Kamrup district are engaged in low category government services. The rests are found in other tertiary sectors like garage works, machine repairing, tailoring etc. Most of the Moria females are housewives comprising about $69.4 \%$, while 15.65 are unemployed. It can be concluded that most of them are trying to cope with adopting new means of livelihood through employment. But some enthusiastic Morias are still struggling to continue with their traditional brass manufacturing though their income is miserable.

It has been found that even today Morias are very ignorant about education and as a result most of them are found with high school level education, whereas an insignificant portion completes graduation. A small section educated in religious schools to get jobs in mosques. On the other hand, while discussing about the female education they are much more backward in this regard. Most of them left school in high school level and get married. Unlike other ethnic tribes of North East India, these Moria women rarely found contributing in family income. This educational backwardness and reluctance for any kind of income generating activities can be explained as the influence of their recently developed religious orthodoxy.

\subsection{CAUSES OF OCCUPATIONAL SHIFTING AMONG MORIA:}

Traditional brass item manufacturing is no more a sustainable livelihood system in today's changing economic scenario. Low income, poor entrepreneurship, Frequent price hike of the raw material, scarcity of brass craps, monopoly of the raw material supplier, presence of middleman, problems of marketing, stagnant low wages of the brass artisans all these can be considered as the factors behind their occupational shifting.

Table2.2: Per Capita Income from Various Occupations

\begin{tabular}{|l|l|l|}
\hline \multirow{2}{*}{ Occupations } & \multicolumn{2}{|l|}{ Annual Per Capita Income (2009) } \\
\cline { 2 - 3 } & Kamrup & Percentage \\
\hline Traditional Brass work & 6211 & 5.30 \\
\hline Cultivation \& wage labour & 15000 & 12.80 \\
\hline Other Tertiary Sectors & 12930 & 11.04 \\
\hline Business and Trade & 39049 & 33.34 \\
\hline Government Service & 43950 & 37.52 \\
\hline Total & 117140 & 100 \\
\hline
\end{tabular}

Source: Field Survey, 2009 
From the above study it can be stated that traditional brass work provide the least amount of the total per capita income, whereas the business and trade category and the government service holders have comparatively higher income. It can be concluded that this low income is the vital cause behind the extinction of this traditional occupation. It is quite obvious that people, in search of better livelihood will surely opt for other options which can support them with a better economic condition. Most of them do not have any savings except the government service holders and businessman and traders. On the other hand the daily wage earners and traditional brass workers have a very little income to save anything. Most of the enterprises are family owned. No separate working shed is available for brass crafting. 'Capital' is another problem. Most of the brass artisans cannot afford to buy raw material themselves and they must depend on the raw material supplier. For brass ware products they get a low amount of daily wages comparing to other wage labourer. From the fixed remuneration the craftsmen have to manage other related expenditures. The artisans informed that the price of brass sheets are increasing day by day from Rs 150 in 2005 to Rs 320 in 2007 and this price hike is still going on. Mean while the daily remuneration of an artisan remains Rs 100 since 2005. Some the brassware manufacturer does not get work regularly now a day. Only 10 to 15 days of work is available in a month against an average 25 to 27 days before. Use of age old machinery is another infrastructural drawback of brassware manufacturing. The units work with traditional manufacturing techniques. No traditional industry can survive unless it has a viable market. The brassware products are generally marketed within the north eastern region. Till date no brass product has been exported. There is no proper arrangement for displaying the products.

\subsection{OCCUPATIONAL DIVERSIFICATION THROUGH THE GENERATIONS OF MORIA IN KAMRUP:}

In present day context traditional brass item manufacturing is unable to provide the Moria people a sustainable livelihood. Therefore an occupational shift can be observed among the Moria inhabitants of Kamrup district for an alternative livelihood strategy. To find out the trend of occupational change, focus is concentrated on the generation wise occupational structure.

Table 2.3: Occupational Trend through Generations of Morias of Kamrup

\begin{tabular}{|c|c|c|c|c|c|c|c|c|c|c|c|c|}
\hline \multirow[t]{3}{*}{ Occupation } & \multicolumn{6}{|c|}{ Age group 20-39 years } & \multicolumn{6}{|c|}{ 40-59 years } \\
\hline & \multicolumn{2}{|c|}{ Interviewee } & \multicolumn{2}{|c|}{ Father } & \multicolumn{2}{|c|}{ Grandfather } & \multicolumn{2}{|c|}{ Interviewee } & \multicolumn{2}{|c|}{ Father } & \multicolumn{2}{|c|}{ Grandfather } \\
\hline & No. & $(\%)$ & No & $(\%)$ & No & $(\%)$ & No. & $(\%)$ & & $(\%)$ & No. & $(\%)$ \\
\hline Wage Labourer & 11 & 7.64 & 11 & 7.64 & 18 & 12.5 & 10 & 7.93 & 7 & $\begin{array}{l}5.5 \\
7\end{array}$ & 2 & 1.6 \\
\hline Brass Worker & 28 & 19.4 & 68 & 47.2 & 102 & 70.83 & 74 & 58.7 & 104 & $\begin{array}{l}82 . \\
5 \\
\end{array}$ & 121 & 96.01 \\
\hline Electrician & 5 & 3.47 & 4 & 2.78 & - & & 2 & 1.6 & 1 & $\begin{array}{l}0.7 \\
9\end{array}$ & - & \\
\hline Machine Repair & 6 & 4.18 & 3 & 2.1 & 2 & 1.38 & 1 & 0.79 & 2 & 1.6 & 1 & 0.79 \\
\hline Garage Worker & 6 & 4.18 & 5 & 3.47 & 2 & 1.38 & 3 & 2.38 & 2 & 1.6 & & \\
\hline LivestockTrader & 3 & 2.1 & 4 & 2.78 & & & 2 & 1.6 & 3 & $\begin{array}{l}2.3 \\
8\end{array}$ & 2 & 1.6 \\
\hline Tailoring & 6 & 4.18 & 3 & 2.1 & 3 & 2.1 & 4 & 3.17 & 2 & 1.6 & & \\
\hline Book Binder & - & & 4 & 2.78 & 5 & 3.47 & & - & 3 & $\begin{array}{l}2.3 \\
8\end{array}$ & & \\
\hline Business/Trade & 50 & 34.7 & 24 & 16.6 & 9 & 6.26 & 11 & 8.73 & 1 & $\begin{array}{l}0.7 \\
9\end{array}$ & & \\
\hline Govt. Service & 21 & 14.6 & 15 & 10.45 & 2 & 1.38 & 19 & 15.1 & 1 & $\begin{array}{l}0.7 \\
9\end{array}$ & & \\
\hline Private & 8 & 5.55 & 3 & 2.1 & 1 & 0.7 & - & & & & & \\
\hline Total & 144 & 100 & & & & & 126 & 100 & & & & \\
\hline
\end{tabular}

Source: Field survey, 2009

The above table shows the diversification of occupation in Kamrup district throughout the generation. Here age group of 20-39 years contains about $19.4 \%$ are engaged in traditional brass crafting, whereas their parent's generation $47.2 \%$ were brass workers and the number of brass workers enhance to $70.83 \%$ in the grandparents generation. New generation Morias are mostly found in various tertiary sectors like business and trade. In this group the father's generation also shows higher participation in business and trade that is $16.6 \%$. In the 40-59 years of age group too, the number of brass artisans comprises $58.7 \%$ among interviewees, $82.5 \%$ in parent's generation and about $96.01 \%$ in grandparent's generation. 
It can be concluded that there is a gradual declination in the participation of brass crafting towards new generation.

\section{Conclusion:}

A trend of occupational diversification has been revealed during the field study. It is already mentioned that the traditional brass item manufacturing contributes the least amount to the total per capita income. As a consequence the Morias shifted to other better source of livelihood. It is quiet natural that occupational structure directly influences the income of the inhabitants, determining their standard of life. Kamrup district Morias. New generation realized that in this changing situation, brass manufacturing is no more sustainable livelihood for them. But at the same time like all the other ethnic community of north-eastern India who take pride in their culture and traditions, the Moria also consider brass crafting as their identity. In this delicate situation a group of Moria is struggling to retain the old dignity and glory of traditional brass crafting.

The study reveals that no such planned programmes were initiated to uplift the traditional brassware industry till now. Although a few training programmes were initiated by SIDBI and SBI with IIT, Guwahati, that was not properly planned according to the requirement of the brass artisans. By enhancing the quality of machineries and organizing proper training to develop the creativity and skill will surely help in the revival of the craft industry. An appropriate step can bring tremendous change to this traditional cottage industry offering employment opportunities to the new generation and ultimately uplifting the socio economic condition of the Moria community. Before providing the Moria youths required training, it is essential to make them aware about the need of education to get profit from the facilities provided to them by the government and other nongovernmental institution. With the cooperation of common people of Assam and the government this glorious traditional occupation of brass crafting can be preserved.

\section{Reference:}

[1] Ali Irshad, A.N.M. (1974): Social Relations among the Assamese Muslims in Rural and Situations, Unpublished PhD Thesis, Pp.99, 224. Gauhati University, Guwahati

[2] Ali, M.I. (2012): A brief Description of the Morias of Kaliabor (Kaliaboror Moria Janagoshthir Chamu Itibritta, p-248

[3] Baruah, G.C. (1930): Ahom Buranji, Assam Administration, Pp.68-73, Calcutta

[4] Baruah, G.C. (1972):Axom Buranji, Assam Prakashan Parishad, Pp. 75-76, Guwahati

[5] Baruah, K.L. (1966): Early History of Kamrup,Dutta Baruah Publication, Guwahati

[6] Bhuyan, S.K. (ed.) (1960): Satsari Axom Buranji, p.69, Publication Department, Gauhati University, Guwahati

[7] Bora, A. (2008): Nere Bhere Moria, Budhbaria, Axomiya Pratidin Chambers,R. and Conway,G.(1991): Sustainable Rural Livelihoods: Practical Concepts for the $21^{\text {st }}$ Century, February $3^{\text {rd }} 2010$ from http://www.smallstoch.info/reference/IDS/dp 296.pdf

[8] Das, G. (2003): Madhyabhugir Kobolot Hajor Aitihyamandita Pital Xilpa, Dainik Janambhumi, p-1, 19 ${ }^{\text {th }}$ October

[9] Das, P.C. (1984): Hajo-a Socio Cultural Study, Unpublished PhD Thesis, Department of Anthropology, Guwahati University, Pp. $25-27$

[10] Duarah, A. (2004): Moria Ali aru Moria Pukhuri, Prantik, Vol.XXIII, 16-31 ${ }^{\text {st }}$ July

[11] Gait, E.A. (1897): The Manufacture of Brass Copper Wares in Assam, Journal of Indian Art and Industry, Voll-III, London

[12] Gait E.A. (1898): Manufacture of Pottery in Assam, Indian Art and the Industry

[13] Gait E.A. (1984): The History of Assam, L.B.S. Publication, Guwahati Guha, P.K. (2007): The Moria Muslims of Assam, Abhijeet Publications, Delhi

[14] Hazarika, H. (2003): Moriaxokolor Pital Xilpa, Amar Axom, p-5, $21^{\text {st }}$ April

[15] Hussain, M. (2003): Aitihyabihin Moria Hulla, Prantik, Vol XXXII, 16-31 $1^{\text {st }}$ August

[16] Hussain, M.I. (2005): Axomor Moria Musolman, Ati Alokpat, Ajir dainik Batori, $6^{\text {th }}$ July

[17] Hussain, M. (2006): Moria Community of Assam: A Sociological Study, Unpublished Thesis, Department of Sociology, Dibrugarh University

[18] O'Neil, D. (2006): Processes of Change, New World EncyclopediaCensus of India (1961) Vol-III, P-26, 27: Selected Handicrafts of Assam Axom Year Book, (2011) P-156, Survey Report from All Assam Moria (Musalman) Santha; 1995. 